\title{
Effect of dietary canthaxanthin and 25-hydroxycholecalciferol supplementation on the performance of duck breeders under two different vitamin regimens
}

Zhouzheng Ren ${ }^{1}$, Shizhen Jiang ${ }^{1}$, Qiufeng Zeng ${ }^{1}$, Xuemei Ding ${ }^{1}$, Shiping Bai ${ }^{1}$, Jianping Wang ${ }^{1}$, Yuheng Luo ${ }^{1}$, Zhuowei Su${ }^{1}$, Yue Xuan ${ }^{1}$, Bing Yao ${ }^{2}$, Fernando Cisneros $^{3}$ and Keying Zhang ${ }^{1 *}$

\begin{abstract}
Background: Dietary canthaxanthin (CX), 25-hydroxycholecalciferol $\left(25-\mathrm{OH}-\mathrm{D}_{3}\right)$ and vitamins have been widely reported to be involved in productive and reproductive performance of broiler breeders. However, limited information is available for duck breeders. In this study, a total of 1,560 Cherry Valley SM3 duck breeder females and 312 males were used to assess if the addition of $\mathrm{CX}$ and $25-\mathrm{OH}-\mathrm{D}_{3}$ could increase the performance of duck breeders under two different dietary vitamin regimens. Four diets were used under a $2 \times 2$ factorial arrangement with 2 kinds of vitamin premixes (REGULAR and HIGH; HIGH premix had higher levels of all vitamins except $\mathrm{K}_{3}$ than REGULAR premix), and with or without the supplementation of the mixture of CX (6 mg/ $\mathrm{kg})$ and $25-\mathrm{OH}-\mathrm{D}_{3}$ $(0.069 \mathrm{mg} / \mathrm{kg})$. The ducks were fed ad libitum with pelleted diets based on corn-soybean meal from 38 to $77 \mathrm{wk}$ of age.
\end{abstract}

Results: HIGH vitamin premix decreased malondialdehyde (MDA) level $(P<0.001)$ of egg yolk, increased hatchability of fertile eggs $(P=0.029)$, increased hatchability of total eggs $(P=0.029)$, and decreased serum protein carbonyl level $(P=0.037)$ of breeder males. The mixture of $\mathrm{CX}$ and $25-\mathrm{OH}-\mathrm{D}_{3}$ increased serum calcium of breeder females $(P=0.010)$, decreased the cracked egg rate $(P=0.001)$, increased the pigmentation of egg yolk $(P<0.001)$ and male bill $(P<0.001)$, and decreased MDA level of egg yolk $(P<0.001)$ and male serum $(P=0.034)$. Interactive effects were observed in cracked egg rate $(P=0.038)$, shell thickness $(P=0.011)$ and serum phosphorus $(P=0.026)$ of breeder females. $\mathrm{HIGH}$ vitamin premix together with the mixture of $\mathrm{CX}$ and $25-\mathrm{OH}-\mathrm{D}_{3}$ decreased cracked egg rate and increased shell thickness of duck breeders. Serum phosphorus was decreased in duck breeder females fed REGULAR vitamin premix without the addition of the $\mathrm{CX}$ and $25-\mathrm{OH}-\mathrm{D}_{3}$ mixture.

Conclusions: Dietary HIGH vitamin premix increased antioxidant status of eggs and breeder males, and increased hatchability. The mixture of $\mathrm{CX}$ and $25-\mathrm{OH}-\mathrm{D}_{3}$ enhanced egg shell quality, and promoted pigmentation and antioxidant status of eggs and breeder males.

Keywords: Canthaxanthin, Duck breeder, Performance, 25-hydroxycholecalciferol, Vitamin

\footnotetext{
* Correspondence: zkeying@sicau.edu.cn

${ }^{1}$ Key Laboratory for Animal Disease-Resistance Nutrition of China Ministry of

Education, Institute of Animal Nutrition, Sichuan Agricultural University,

Chengdu 611130, Sichuan, China

Full list of author information is available at the end of the article
} 


\section{Background}

Breeder poultry dietary vitamins must be provided in the correct amount and form for optimal animal health and productivity. However, vitamin requirements of duck breeders have been rarely researched in recent decades. Although the vitamin requirements for White Pekin duck breeders were given by NRC (1994) [1], the recommendations for most vitamins were estimated based on values obtained from other ages or species, and have often been criticized to bear little relationship with the levels currently used in the industry. In commercial farms, the duck breeders' vitamin supplementation is always based on recommendations for broiler breeders, and some of the vitamins are formulated into premix without considering the interaction between vitamins [2, 3]. Unbalanced composition of the premix decreases the utilization efficiency of vitamins and does not show an accurate picture of the productive and reproductive potential of duck breeders [4, 5]. A rational use of dietary vitamin premix might be beneficial for poultry producers.

Canthaxanthin (CX, an important carotenoid) and 25hydroxycholecalciferol (25-OH-D $\mathbf{D}_{3}$, one of the vitamin $\mathrm{D}_{3}$ metabolites) are also potential dietary factors that could be used to benefit the health and performance of poultry breeders. Canthaxanthin is a powerful immunostimulant [6] and antioxidant [7], and it plays important roles in signaling secondary sexual characteristics in animals [8]. Surai et al. [7] and Zhang et al. [9] reported that CX could modulate the antioxidant status and positively influence the performance of broiler breeders. Rosa et al. [10] confirmed that dietary CX supplementation could increase the fertility and hatchability of broiler breeders. The nutritional role of $25-\mathrm{OH}-\mathrm{D}_{3}$ has received considerable attention because of its involvement in calcium-phosphorus metabolism and immune response [11]. The use of $25-\mathrm{OH}-\mathrm{D}_{3}$ has been reported to increase egg production, shell quality, hatchability and progeny health of hens [12-15]. Based on these reports, we hypothesized that the diet presently used in the duck breeder industry will be insufficient in CX and $25-\mathrm{OH}-\mathrm{D}_{3}$ for productive and reproductive goals.

In the present study, productive, reproductive performance, antioxidant status and serum calciumphosphorus levels of Cherry Valley duck breeders from 38 to $77 \mathrm{wk}$ were assessed to examine the influence of supplementation of $\mathrm{CX}$ and $25-\mathrm{OH}-\mathrm{D}_{3}$ under two different dietary vitamin regimens.

\section{Methods}

\section{Trial design and diets}

There were four dietary treatments in a $2 \times 2$ experimental arrangement with two vitamin premixes (REGULAR and HIGH) and with or without the supplementation of the mixture of CX $(6 \mathrm{mg} / \mathrm{kg})$ and $25-\mathrm{OH}-\mathrm{D}_{3}(0.069 \mathrm{mg} / \mathrm{kg})$. The REGULAR level premix was formulated to simulate a commercial premix used in the duck industry in China; and the HIGH premix was designed according to the recommendations in SM3 Commercial Duck Management Manual [16] which is in good match with the DSM Vitamin Supplementation Guidelines (reported as optimum vitamin nutrition for animals) recommended by DSM Nutritional Products Ltd. [17, 18]. All the vitamins, $\mathrm{CX}$ and $25-\mathrm{OH}-\mathrm{D}_{3}$ used in the present trial were provided by DSM (China) Ltd. (Chengdu, Sichuan Province, P. R. China). Each treatment contained 3 pens with 130 females and 26 males per pen. In total, 1,560 breeder females and 312 males were fed cornsoybean meal-based pelleted diets (particle size $=4.5 \mathrm{~mm}$ ) from 38 to 77 wk of age (Table 1$)$.

\section{Bird care}

The trial was conducted at Jinyan breeding farm in Mianzhu, Sichuan Province, P. R. China. Duck breeders were fed on straw litter floors $(7 \mathrm{~m} \times 7 \mathrm{~m})$ with an outside area $(7 \mathrm{~m} \times 10.5 \mathrm{~m})$ including a swimming pool $(1 \mathrm{~m} \times 2 \mathrm{~m} \times 0.4 \mathrm{~m}$ in width $\times$ length $\times$ depth), a drinker and a feeder. There were no other vitamins or drugs used beyond the feed. Feed and water were supplied ad libitum, and a 17 light: 7 dark photo-period was used during the trial. Experimental procedures were approved by the Animal Care and Use Committee, Sichuan Agricultural University.

\section{Laying performance and egg quality}

Eggs from each pen were collected every morning, identified and recorded. Setting eggs were stored for a maximum period of $7 \mathrm{~d}$ at 15 to $16{ }^{\circ} \mathrm{C}$ and 70 to $75 \% \mathrm{RH}$ until transferred to the incubator. The laying performance (daily laying rate, daily feed intake, egg weight, total egg mass, feed: egg ratio and cracked eggs) per pen was calculated weekly. A DSM Color Fan ${ }^{\text {TM }}$ (DSM Ltd.) was used on the last d of wk 4, 8, 12, 16, 24, 32 and 40 of the trial to measure the bill and shank pigmentation of 6 males per pen. At wk 8, 16, 24, 32 and 40 of the trial, 12 setting eggs per treatment (3 pens of 4 eggs each) produced on the last $\mathrm{d}$ were used to determine egg shape index (long axis: short axis, $\mathrm{mm}$ : $\mathrm{mm}$ ), yolk pigmentation [EMT-5200 (Robotmation, Co., Ltd., Tokyo, Japan)], shell thickness [mm, ETG-1061A (Robotmation, Co., Ltd., Tokyo, Japan)], shell strength $\left[\mathrm{kg} / \mathrm{cm}^{2}\right.$, EFG-0503 (Robotmation, Co., Ltd., Tokyo, Japan)], shell ratio (shell weight: egg weight, \%), albumen height (mm, EMT-5200) and Haugh units [Haugh units = 100 log $\left(\mathrm{H}-1.7 \mathrm{~W}^{0.37}+7.57\right)$, in which $\mathrm{H}=$ height of albumen $(\mathrm{mm})$ and $\mathrm{W}=$ egg weight $(\mathrm{g})]$. 
Table 1 Composition and nutrient levels of the basal diet (fed-basis)

\begin{tabular}{|c|c|}
\hline Item, \% & Amount \\
\hline \multicolumn{2}{|l|}{ Ingredient } \\
\hline Corn & 24.4 \\
\hline Soybean meal, 43 \% & 22.0 \\
\hline Wheat flour & 20.0 \\
\hline Rice bran & 15.0 \\
\hline Rice bran meal & 2.9 \\
\hline Rapeseed meal & 5.0 \\
\hline Meat and bone meal & 3.5 \\
\hline Calcium carbonate & 6.3 \\
\hline L-Lysine- $\mathrm{H}_{2} \mathrm{SO}_{4}$ & 0.13 \\
\hline D, L-methionine & 0.12 \\
\hline Sodium chloride & 0.3 \\
\hline Choline chloride, $50 \%$ & 0.1 \\
\hline Premix ${ }^{a, b}$ & 0.25 \\
\hline \multicolumn{2}{|l|}{ Analyzed nutrient content } \\
\hline $\mathrm{CP}$ & 20.68 \\
\hline Calcium & 3.020 \\
\hline Total phosphorus & 0.810 \\
\hline DM & 86.73 \\
\hline \multicolumn{2}{|l|}{ Calculated nutrient content } \\
\hline $\mathrm{ME}, \mathrm{MJ} / \mathrm{kg}$ & 11.00 \\
\hline Nonphytate phosphorus & 0.303 \\
\hline Lysine & 1.087 \\
\hline Methionine & 0.446 \\
\hline Methionine + Cystine & 0.705 \\
\hline Threonine & 0.749 \\
\hline Tryptophan & 0.263 \\
\hline
\end{tabular}

${ }^{a}$ Supplied per kilogram of diet: copper, $12 \mathrm{mg}$; iron, $70 \mathrm{mg}$; zinc, $80 \mathrm{mg}$; manganese, $100 \mathrm{mg}$; selenium, $0.25 \mathrm{mg}$; iodine, $0.2 \mathrm{mg}$

b Supplied per kilogram of diet. REGULAR vitamin premix: vitamin A, 10,000 IU; vitamin $\mathrm{D}_{3}, 3,000 \mathrm{IU}$; vitamin $\mathrm{K}_{3}, 5 \mathrm{mg}$; vitamin $\mathrm{E}, 30 \mathrm{mg}$; vitamin $\mathrm{B}_{1}, 4 \mathrm{mg}$; vitamin $B_{2}, 6 \mathrm{mg}$; vitamin $B_{6}, 4 \mathrm{mg}$; vitamin $B_{12}, 0.015 \mathrm{mg}$; nicotine acid, $50 \mathrm{mg}$; pantothenic acid, 15 ; biotin, $0 \mathrm{mg}$; folic acid, $1 \mathrm{mg}$. HIGH vitamin premix: vitamin $A, 15,000 \mathrm{IU}$; vitamin $\mathrm{D}_{3}, 4,000 \mathrm{IU}$; vitamin $\mathrm{K}_{3}, 5 \mathrm{mg}$; vitamin $\mathrm{E}$, $100 \mathrm{mg}$; vitamin $B_{1}, 5 \mathrm{mg}$; vitamin $B_{2}, 16$ mg; vitamin $B_{6}, 5 \mathrm{mg}$; vitamin $B_{12}$, $0.025 \mathrm{mg}$; nicotine acid, $60 \mathrm{mg}$; pantothenic acid, 20; biotin, $0.2 \mathrm{mg}$; folic acid, $2.5 \mathrm{mg}$

\section{Incubation conditions}

At wk 8, 12, 16, 20, 24, 28, 32, 36 and 40 of the trial, 126 setting eggs per pen were randomly chosen to determine the fertility and hatchability. The incubation was conducted with a commercial incubator (Yiai 12096, made in Qingdao, China). The temperature was controlled as $37.8,37.6$ and $37.5{ }^{\circ} \mathrm{C}$ during $\mathrm{d} 1$ to 14,15 to 21 and 22 to 25 of incubation at $60 \%$ humidity. We candled eggs at $\mathrm{d} 7$ of incubation to determine the fertility (expressed as the percentage of fertilized eggs in incubated eggs). At d 26 of incubation, eggs were transferred to a hatcher with $36.5{ }^{\circ} \mathrm{C}$ and $70 \% \mathrm{RH}$ to complete the incubation process. At $\mathrm{d} 28$, ducklings were removed from the hatcher, then recorded, weighed and their health status was assessed. Ducklings were considered healthy when they were clean and dry, were free of abnormalities, had complete umbilical scarring, and had bright eyes. The hatchability of fertile eggs was expressed as the number of ducklings obtained from every 100 fertilized eggs, the hatchability of setting eggs was expressed as the number of ducklings obtained from every 100 incubated eggs, and the hatchability of total eggs was expressed as the number of ducklings obtained from every 100 eggs laid by duck breeders. Otherwise, the incubation data from each pen throughout the $40 \mathrm{wk}$ trial was summarized, and the following traits were calculated: fertilized eggs per housed female, ducklings per housed female, and healthy ducklings per housed female.

\section{Serum and yolk analysis}

After $40 \mathrm{wk}$ of the laying trial, 9 females (3 females were taken from each of the three pens) and 6 males ( 2 males were taken from each of the three pens) per treatment were randomly chosen and bled for the determination of antioxidant status. Blood from wing veins was taken by sterilized needles and allowed to clot at room temperature for $2 \mathrm{~h}$ before centrifuged at $1,200 \times \mathrm{g}$ for $10 \mathrm{~min}$ at $4{ }^{\circ} \mathrm{C}$ to obtain serum. Serum samples were stored at $-20{ }^{\circ} \mathrm{C}$ until analyzed for calcium, phosphorus and antioxidant status. In addition, at wk 8, 16, 24, 32 and 40 of the trial, 12 eggs (4 eggs were taken from each of the three pens) per treatment were randomly chosen and the yolk of each egg was separated and stored at $-20{ }^{\circ} \mathrm{C}$ for analysis. Malondialdehyde (MDA) and protein carbonyl were used to evaluate the antioxidant status of serum and yolk.

Serum and yolk were treated with thiobarbituric acid to generate a colored product to measure MDA (as a measure of lipid oxidation) content. Colorimetric method was used to measure the colored product at $532 \mathrm{~nm}$ [19].

Serum and yolk protein carbonyl contents were measured using a modification of the method reported by Reznick et al. [20]. Briefly, samples were dissolved using a dinitrophenylhydrazine (DNPH)- $\mathrm{HCl}$ solution (blanks were conducted simultaneously by using $\mathrm{HCl}$ alone), vortexed for $1 \mathrm{~min}$, then heated in a $37{ }^{\circ} \mathrm{C}$ water bath for $30 \mathrm{~min}$ in darkness. After the water bath process, proteins were precipitated using trichloroacetic acid and the sediments were washed four times with an absolute ethyl alcohol/ethyl acetate mixture (1:1). Washings were carried out by vortexing of the sediments in the washing solution, and centrifugation at $13,800 \times \mathrm{g}$ for $10 \mathrm{~min}$ at $4{ }^{\circ} \mathrm{C}$. Finally, the sediments were solubilized in $6 \mathrm{M}$ guanidine- $\mathrm{HCl}$ solution and the absorbance was 
measured at $370 \mathrm{~nm}$. In addition, total protein content of the samples was measured using a Coomassie Brilliant Blue (CBB) method [21] and results were expressed as nanomoles of protein carbonyl in per gram of protein.

Kits for calcium, phosphorus, MDA, protein carbonyl and $\mathrm{CBB}$ used in this trial were obtained from Nanjing Jiancheng Bioengineering Institute (Nanjing, Jiangsu Province, P. R. China).

\section{Statistical analysis}

Data were analyzed by ANOVA as a $2 \times 2$ factorial using GLM procedures of SPSS 17.0 (SPSS Inc., Chicago, IL). The main effects (vitamin premix, mixture of $\mathrm{CX}$ and $25-\mathrm{OH}-\mathrm{D}_{3}$ ) and interactions between the two factors were carried out. Duncan's test was applied when any of the interactions showed significance. Pen was the experimental unit. Data are shown as the LSmeans and pooled SEM. The results were considered significantly different at $P \leq 0.05$.

\section{Results}

\section{Laying performance}

The laying performance of duck breeders is presented in Table 2. Neither vitamin premix nor the mixture of CX and $25-\mathrm{OH}-\mathrm{D}_{3}$ affected daily laying rate, daily feed intake, egg weight, total egg mass and feed: egg ratio of duck breeders $(P>0.05)$. However, the supplementation of the mixture of $\mathrm{CX}$ and $25-\mathrm{OH}-\mathrm{D}_{3}$ increased the bill pigmentation $(P<0.001)$ and shank pigmentation $(P<0.001)$ of breeder males. Moreover, the cracked egg rate was decreased $(P=0.001)$ by the addition of the mixture of $\mathrm{CX}$ and $25-\mathrm{OH}-\mathrm{D}_{3}$, and a significant interaction $(P=0.038$, vitamin premixes $\times$ mixture of $\mathrm{CX}$ and $\left.25-\mathrm{OH}-\mathrm{D}_{3}\right)$ was observed in cracked egg rate which was minimized when breeders were fed with HIGH vitamin premix together with the supplementation of the mixture of $\mathrm{CX}$ and $25-\mathrm{OH}-\mathrm{D}_{3}$. There were no interactions in other laying traits $(P>0.05)$.

\section{Egg quality}

Supplementation of the mixture of $\mathrm{CX}$ and $25-\mathrm{OH}-\mathrm{D}_{3}$ significantly increased the yolk pigmentation $(P<0.001$, Table 3). Interaction between vitamin premix and the $\mathrm{CX}$ and 25-OH- $\mathrm{D}_{3}$ mixture was found in shell thickness $(P=0.011)$. HIGH vitamin premix together with the mixture of $\mathrm{CX}$ and $25-\mathrm{OH}-\mathrm{D}_{3}$ significantly increased egg shell thickness.

\section{Fertility and hatchability}

Dietary HIGH vitamin premix increased the hatchability of fertile eggs $(P=0.029$, Table 4$)$ and the hatchability of total eggs $(P=0.029)$. However, individual or interactive effects of vitamin premix and the $\mathrm{CX}$ and $25-\mathrm{OH}-\mathrm{D}_{3}$ mixture were not found $(P>0.05)$ in the following traits: fertility, fertilized eggs per housed female, hatchability of setting eggs, ducklings per housed female, healthy ducklings, healthy ducklings per housed female, and 1-d-old weight of ducklings.

\section{Antioxidant status}

HIGH vitamin premix decreased the MDA level of egg yolks $(P<0.001)$ and the serum protein carbonyl level of males $(P=0.037$, Table 5$)$. The MDA level of egg yolks $(P=0.034)$ and male serum $(P=0.034)$ were decreased with the supplementation of the $\mathrm{CX}$ and $25-\mathrm{OH}-\mathrm{D}_{3}$ mixture in feed. However, the antioxidant status of breeder females was not affected $(P>0.05)$ by the two experimental factors. No significant interactions were observed in the antioxidant status traits $(P>0.05)$.

Table 2 Laying performance of duck breeders from 38 to 77 wk of age ${ }^{d}$

\begin{tabular}{|c|c|c|c|c|c|c|c|c|c|}
\hline \multirow[t]{2}{*}{ Vitamin level } & \multirow[t]{2}{*}{$\mathrm{CX}+25-\mathrm{OH}-\mathrm{D}_{3}$} & \multirow{2}{*}{$\begin{array}{l}\text { Daily laying } \\
\text { rate, \% }\end{array}$} & \multirow{2}{*}{$\begin{array}{l}\text { Daily feed } \\
\text { intake, } g\end{array}$} & \multirow{2}{*}{$\begin{array}{l}\text { Egg } \\
\text { weight, g }\end{array}$} & \multirow{2}{*}{$\begin{array}{l}\text { Total egg } \\
\text { mass, kg }\end{array}$} & \multirow{2}{*}{$\begin{array}{l}\text { Feed: egg, } \\
\text { kg:kg }\end{array}$} & \multirow{2}{*}{$\begin{array}{l}\text { Cracked } \\
\text { eggs, \% }\end{array}$} & \multicolumn{2}{|c|}{ Pigmentation of males $^{\mathrm{e}}$} \\
\hline & & & & & & & & Bill & Shank \\
\hline REGULAR & - & 82.7 & 239 & 92.1 & 21.3 & 3.80 & $1.4^{\mathrm{ab}}$ & 7.6 & 10.4 \\
\hline REGULAR & + & 81.2 & 236 & 91.6 & 20.8 & 3.82 & $1.3^{\mathrm{b}}$ & 10.7 & 14.7 \\
\hline $\mathrm{HIGH}$ & - & 83.9 & 239 & 92.1 & 21.6 & 3.74 & $1.5^{\mathrm{a}}$ & 7.8 & 10.8 \\
\hline $\mathrm{HIGH}$ & + & 82.6 & 237 & 92.5 & 21.4 & 3.74 & $1.1^{\mathrm{c}}$ & 11.0 & 14.9 \\
\hline SEM & & 0.7 & 1.0 & 0.2 & 0.2 & 0.03 & 0.04 & 0.5 & 0.6 \\
\hline \multicolumn{10}{|l|}{$P$-value } \\
\hline \multicolumn{2}{|l|}{ Vitamin } & 0.373 & 0.831 & 0.216 & 0.324 & 0.297 & 0.305 & 0.065 & 0.062 \\
\hline \multicolumn{2}{|c|}{$\mathrm{CX}+25-\mathrm{OH}-\mathrm{D}_{3}$} & 0.366 & 0.179 & 0.885 & 0.409 & 0.900 & 0.001 & $<0.001$ & $<0.001$ \\
\hline \multicolumn{2}{|c|}{ Vitamin $\times\left(C X+25-O H-D_{3}\right)$} & 0.946 & 0.737 & 0.168 & 0.763 & 0.821 & 0.038 & 0.794 & 0.419 \\
\hline
\end{tabular}

a-c Different superscripts in a row indicate differ significantly $(P \leq 0.05)$

${ }^{d} \mathrm{CX}$ canthaxanthin, 25-OH- $\mathrm{D}_{3}$ 25-hydroxycholecalciferol

e Mean of 7 times of color measure at wk 4, 8, 12, 16, 24, 32 and 40 of the trial 
Table 3 Egg quality of duck breeders from 38 to 77 wk of age ${ }^{c, d}$

\begin{tabular}{|c|c|c|c|c|c|c|c|c|}
\hline Vitamin level & $\mathrm{CX}+25-\mathrm{OH}-\mathrm{D}_{3}$ & $\begin{array}{l}\text { Egg shape index } \\
\text { (long:short) }\end{array}$ & $\begin{array}{l}\text { Yolk } \\
\text { pigmentation }\end{array}$ & Shell thickness, mm & $\begin{array}{l}\text { Shell strength, } \\
\mathrm{kg} / \mathrm{cm}^{2}\end{array}$ & Shell ratio, \% & $\begin{array}{l}\text { Albumen } \\
\text { height, mm }\end{array}$ & $\begin{array}{l}\text { Haugh } \\
\text { units }\end{array}$ \\
\hline REGULAR & - & 1.349 & 1.9 & $0.334^{\mathrm{ab}}$ & 4.00 & 9.9 & 8.2 & 80.6 \\
\hline REGULAR & + & 1.341 & 12.6 & $0.325^{b}$ & 3.97 & 9.8 & 8.6 & 83.0 \\
\hline $\mathrm{HIGH}$ & - & 1.347 & 2.1 & $0.324^{b}$ & 4.10 & 9.9 & 8.3 & 81.2 \\
\hline $\mathrm{HIGH}$ & + & 1.344 & 12.5 & $0.342^{\mathrm{a}}$ & 4.24 & 10.0 & 8.7 & 83.2 \\
\hline SEM & & 0.004 & 0.4 & 0.002 & 0.07 & 0.1 & 0.1 & 0.8 \\
\hline \multicolumn{9}{|l|}{$P$-value } \\
\hline \multicolumn{2}{|l|}{ Vitamin } & 0.934 & 0.914 & 0.779 & 0.128 & 0.436 & 0.668 & 0.732 \\
\hline \multicolumn{2}{|c|}{$\mathrm{CX}+25-\mathrm{OH}-\mathrm{D}_{3}$} & 0.477 & $<0.001$ & 0.189 & 0.758 & 0.866 & 0.233 & 0.264 \\
\hline \multicolumn{2}{|c|}{ Vitamin $\times\left(\mathrm{CX}+25-\mathrm{OH}-\mathrm{D}_{3}\right)$} & 0.761 & 0.382 & 0.011 & 0.688 & 0.412 & 0.833 & 0.897 \\
\hline
\end{tabular}

$\overline{\mathrm{a}, \mathrm{b}}$ Different superscripts in a row indicate differ significantly $(P \leq 0.05)$

c Mean of 5 times of sample analysis at $w k 8,16,24,32$ and 40 of the trial

${ }^{d} \mathrm{CX}$ canthaxanthin, 25-OH- $\mathrm{D}_{3}$ 25-hydroxycholecalciferol

\section{Serum calcium and phosphorus}

Serum calcium levels of breeder females were greatly increased $(P=0.010$, Table 6$)$ by the supplementation of the mixture of $\mathrm{CX}$ and $25-\mathrm{OH}-\mathrm{D}_{3}$ in diet. Interaction between vitamin premix and the $\mathrm{CX}$ and $25-\mathrm{OH}-\mathrm{D}_{3}$ mixture was found to influence the serum phosphorus of breeder females $(P=0.026)$. Decreased level of serum phosphorus was observed in duck breeder females under REGULAR vitamin premix without the addition of the $\mathrm{CX}$ and $25-\mathrm{OH}-\mathrm{D}_{3}$ mixture. There were no differences $(P>0.05)$ between treatments in serum calcium and phosphorus levels of males.

\section{Discussion}

Studies of the application of $25-\mathrm{OH}-\mathrm{D}_{3}$ in laying hen diets containing higher than NRC (1994) [1] recommended level of vitamin $\mathrm{D}_{3}$ remain controversial. Roland and Harms [22] reported that the supplementation of $25-\mathrm{OH}-\mathrm{D}_{3}(1.1 \mathrm{mg} / \mathrm{kg})$ had no significant effect on the laying performance of hens fed a basal diet containing $2200 \mathrm{IU} / \mathrm{kg}$ vitamin $\mathrm{D}_{3}$. However, Torres et al. [23] found that the supplementation of $25-\mathrm{OH}-\mathrm{D}_{3}$ (0.035 or $0.069 \mathrm{mg} / \mathrm{kg}$ ) in diets containing $2000 \mathrm{IU} / \mathrm{kg}$ vitamin $\mathrm{D}_{3}$ resulted in increased egg shell quality. In the study of Zang et al. [24], hens fed a diet containing $2500 \mathrm{IU} / \mathrm{kg}$ vitamin $\mathrm{D}_{3}$ and $0.035 \mathrm{mg} / \mathrm{kg} 25-\mathrm{OH}-\mathrm{D}_{3}$ had a reduced number of cracked eggs when compared with a diet containing $2400 \mathrm{IU} / \mathrm{kg}$ vitamin $\mathrm{D}_{3}$ without $25-\mathrm{OH}-\mathrm{D}_{3}$. Similarly, in this study, dietary supplementation of the CX and $25-\mathrm{OH}-\mathrm{D}_{3}$ mixture made no effect on egg production; but decreased cracked egg percent of duck breeders, even both the Regular and the High vitamin premixes had higher level of vitamin $D_{3}$ than NRC (1994) [1] recommendation. In these studies, different responses to $25-\mathrm{OH}-\mathrm{D}_{3}$ supplementation were observed when the desired criteria were changed. Response in egg shell quality occurred with $25-\mathrm{OH}-\mathrm{D}_{3}$ supplementation above the requirement for egg production. Interestingly, lowest cracked egg rate and highest shell thickness were achieved in the highest total vitamin D supplementation group (HIGH premix together with the $\mathrm{CX}$ and 25-OH$\mathrm{D}_{3}$ mixture). Based on these data, we speculate that a reevaluation of the NRC (1994) [1] vitamin $\mathrm{D}_{3}$ recommendation (900 IU/kg) for duck breeders might be needed when using egg shell quality as the parameter. In this study, the supplementation of the mixture of CX and 25-OH- $\mathrm{D}_{3}$ also increased female serum calcium level, which may partially account for the increased shell quality [25]. In REGULAR vitamin premix groups, the increased female serum phosphorus induced by $\mathrm{CX}$ and 25-OH-D 3 supplementation may be explained by increased intestinal phosphorus absorption because of increased 1, 25 dihydroxyvitamin $\mathrm{D}_{3}$ synthesis [26].

Higher than NRC (1994) [1] levels of vitamins have many times been reported to reveal no beneficial effects on egg production of laying hens [15, 22, 24]. However, hens revealed to have greater vitamin requirements for hatchability than for laying, as increased hatchability was achieved by maternal supplementation of high levels of vitamins [27, 28]. Similarly, in the current study, maternal HIGH vitamin premix made no effects on egg production, but increased the hatchability of fertile eggs and the hatchability of total eggs. In the avian system, the embryo develops outside the maternal body, and all the nutrients required by the embryo are pre-deposited inside the egg during egg formation. A balanced nutritional status of breeder eggs is essential for the development of embryo $[29,30]$. In the current study, the increased levels of vitamins in HIGH premix may have helped to modify the vitamin composition of duck breeder eggs [7, 24, 31], and benefit the embryo development. Egg production has long been used as the key criteria to evaluate the vitamin requirement of hens. However, parameters for assessing needs are now more 
Table 4 Fertility and hatchability of duck breeders from 38 to 77 wk of age ${ }^{a, b}$

\begin{tabular}{|c|c|c|c|c|c|c|c|c|c|c|}
\hline Vitamin level & $\mathrm{CX}+25-\mathrm{OH}-\mathrm{D}_{3}$ & Fertility, \% & $\begin{array}{l}\text { Fertilized eggs } \\
\text { (per housed female) }\end{array}$ & $\begin{array}{l}\text { Hatchability of } \\
\text { fertile eggs, \% }\end{array}$ & $\begin{array}{l}\text { Hatchability of } \\
\text { setting eggs, } \%\end{array}$ & $\begin{array}{l}\text { Hatchability of } \\
\text { total eggs, \% }\end{array}$ & $\begin{array}{l}\text { Ducklings (per } \\
\text { housed female) }\end{array}$ & $\begin{array}{l}\text { Healthy } \\
\text { duckling, \% }\end{array}$ & $\begin{array}{l}\text { Healthy ducklings } \\
\text { (per housed female) }\end{array}$ & 1-d-old weight, $g$ \\
\hline REGULAR & - & 87.7 & 163.7 & 91.7 & 80.4 & 77.4 & 150.2 & 90.8 & 136.3 & 59.2 \\
\hline REGULAR & + & 88.9 & 161.7 & 90.9 & 80.8 & 77.5 & 147.1 & 91.1 & 134.1 & 58.8 \\
\hline $\mathrm{HIGH}$ & - & 87.7 & 161.3 & 93.1 & 81.6 & 78.4 & 150.1 & 90.6 & 136.0 & 59.4 \\
\hline $\mathrm{HIGH}$ & + & 89.6 & 167.9 & 92.9 & 83.1 & 80.1 & 155.8 & 92.7 & 144.5 & 59.6 \\
\hline \multicolumn{2}{|l|}{ SEM } & 0.4 & 2.6 & 0.4 & 0.5 & 0.5 & 2.6 & 0.4 & 2.5 & 0.2 \\
\hline \multicolumn{2}{|l|}{ Vitamin } & 0.704 & 0.759 & 0.029 & 0.065 & 0.029 & 0.475 & 0.353 & 0.368 & 0.332 \\
\hline \multicolumn{2}{|l|}{$\mathrm{CX}+25-\mathrm{OH}-\mathrm{D}_{3}$} & 0.106 & 0.711 & 0.430 & 0.256 & 0.207 & 0.826 & 0.147 & 0.574 & 0.794 \\
\hline \multicolumn{2}{|c|}{ Vitamin $\times\left(C X+25-O H-D_{3}\right)$} & 0.721 & 0.491 & 0.657 & 0.516 & 0.276 & 0.470 & 0.255 & 0.340 & 0.592 \\
\hline
\end{tabular}

${ }^{a}$ Mean of 9 times of incubation at wk 8,12, 16, 20, 24, 28, 32, 36 and 40 of the trial

${ }^{b} \mathrm{CX}$ canthaxanthin, $25-\mathrm{OH}-\mathrm{D}_{3} 25$-hydroxycholecalciferol 
Table 5 Antioxidant status of duck breeders and eggs ${ }^{a}$

\begin{tabular}{|c|c|c|c|c|c|c|c|}
\hline \multirow[t]{2}{*}{ Vitamin level } & \multirow[t]{2}{*}{$\mathrm{CX}+25-\mathrm{OH}-\mathrm{D}_{3}$} & \multicolumn{2}{|l|}{ Female } & \multicolumn{2}{|l|}{ Male } & \multicolumn{2}{|l|}{ Egg yolk } \\
\hline & & $\mathrm{MDA}, \mathrm{nmol} / \mathrm{mL}$ & $\begin{array}{l}\text { Protein carbonyl, } \\
\mathrm{nmol} / \mathrm{mgpro}\end{array}$ & $\mathrm{MDA}, \mathrm{nmol} / \mathrm{mL}$ & $\begin{array}{l}\text { Protein carbonyl, } \\
\mathrm{nmol} / \mathrm{mgpro}\end{array}$ & $\mathrm{MDA}, \mathrm{nmol} / \mathrm{mL}$ & $\begin{array}{l}\text { Protein carbonyl, } \\
\mathrm{nmol} / \mathrm{mgpro}\end{array}$ \\
\hline REGULAR & - & 10.41 & 0.95 & 8.90 & 1.23 & 235.81 & 22.01 \\
\hline REGULAR & + & 10.13 & 0.79 & 7.71 & 1.03 & 181.21 & 21.51 \\
\hline $\mathrm{HIGH}$ & - & 10.45 & 0.80 & 7.92 & 0.73 & 174.69 & 20.99 \\
\hline $\mathrm{HIGH}$ & + & 9.27 & 0.71 & 7.05 & 0.91 & 156.86 & 18.89 \\
\hline SEM & & 0.30 & 0.13 & 0.25 & 0.08 & 5.34 & 0.65 \\
\hline \multicolumn{8}{|l|}{$P$-value } \\
\hline \multicolumn{2}{|l|}{ Vitamin } & 0.505 & 0.665 & 0.084 & 0.037 & $<0.001$ & 0.175 \\
\hline \multicolumn{2}{|c|}{$\mathrm{CX}+25-\mathrm{OH}-\mathrm{D}_{3}$} & 0.235 & 0.641 & 0.034 & 0.934 & $<0.001$ & 0.302 \\
\hline \multicolumn{2}{|c|}{ Vitamin $\times\left(C X+25-O H-D_{3}\right)$} & 0.460 & 0.895 & 0.729 & 0.204 & 0.073 & 0.516 \\
\hline
\end{tabular}

${ }^{a} \mathrm{CX}$ canthaxanthin, 25-OH- $\mathrm{D}_{3}$ 25-hydroxycholecalciferol, MDA malondialdehyde

${ }^{b}$ Mean of 5 times of sample analysis at wk 8, 16, 24, 32 and 40 of the trial

complex as more and more focus goes to the reproductive efficiency and health of offspring [15, 28, 32]. Information on vitamin requirements of duck breeders is surprisingly lacking in recent years. Our data indicates that the current REGULAR vitamin premix provides enough vitamins for the laying performance of duck breeders; however, more vitamins might be required for breeding purposes (e.g. hatchability). In addition, the vitamin levels in the current HIGH vitamin premix are in accordance with the commercial recommendations for broiler breeders [17, 33]. Thus, our results indicate that duck breeders probably have similar vitamin requirements as broiler breeders for reproductive performance.

Many vitamins (e.g., vitamin A, C, E, and B1) and pigments (e.g., carotenoids) have been reported to exert antioxidant activity $[9,10,28,34]$. In this study, either HIGH vitamin premix or the supplementation of the mixture of $\mathrm{CX}$ and 25-OH- $\mathrm{D}_{3}$ decreased the level of MDA, a lipid peroxidation product, in breeder egg yolk. Chicken embryo is known to undergo reactive oxygen species (ROS) formation and lipid peroxidation during the incubation period due to its high polyunsaturated fatty acid contents [35]. The decreased MDA level in egg yolk may further help to reduce the lipid peroxidation and increase the health status of the developing embryo [36]. These data also offer an approach to reduce the economic loss caused by high temperature stress or long-term breeder egg storage, which may increase lipid peroxidation status of breeder eggs and reduce hatchability [33, 37]. The role of CX in yolk pigmentation has been well characterized [38]. Similarly, in the current study, yolk pigmentation was increased by the addition of the mixture of $\mathrm{CX}$ and $25-\mathrm{OH}-\mathrm{D}_{3}$.

In the present study, the antioxidant and pigmentation status of duck breeder males showed the same trend like the egg yolks as affected by ether HIGH vitamin premix or the supplementation of the $\mathrm{CX}$ and $25-\mathrm{OH}-\mathrm{D}_{3}$ mixture. In male animals, it is well established that an enhanced antioxidant status correlates with increased semen quality [39]. The current results indicate a potential role of dietary antioxidants in improving the reproductive performance of duck breeder males. The

Table 6 Serum calcium and phosphorus levels of duck breeders ${ }^{c}$

\begin{tabular}{|c|c|c|c|c|c|}
\hline \multirow[t]{2}{*}{ Vitamin level } & \multirow[t]{2}{*}{$\mathrm{CX}+25-\mathrm{OH}-\mathrm{D}_{3}$} & \multicolumn{2}{|l|}{ Female } & \multicolumn{2}{|l|}{ Male } \\
\hline & & Calcium, mmol/L & Phosphorus, mmol/L & Calcium, $\mathrm{mmol} / \mathrm{L}$ & Phosphorus, mmol/L \\
\hline REGULAR & - & 2.92 & $2.70^{\mathrm{b}}$ & 2.18 & 1.07 \\
\hline REGULAR & + & 3.42 & $3.67^{\mathrm{a}}$ & 2.47 & 1.62 \\
\hline $\mathrm{HIGH}$ & - & 3.12 & $3.83^{\mathrm{a}}$ & 2.42 & 1.58 \\
\hline $\mathrm{HIGH}$ & + & 3.25 & $3.52^{\mathrm{a}}$ & 2.50 & 1.63 \\
\hline SEM & & 0.06 & 0.15 & 0.05 & 0.09 \\
\hline \multicolumn{6}{|l|}{$P$-value } \\
\hline \multicolumn{2}{|l|}{ Vitamin } & 0.889 & 0.085 & 0.208 & 0.151 \\
\hline \multicolumn{2}{|c|}{$\mathrm{CX}+25-\mathrm{OH}-\mathrm{D}_{3}$} & 0.010 & 0.245 & 0.077 & 0.100 \\
\hline \multicolumn{2}{|c|}{ Vitamin $\times\left(C X+25-O H-D_{3}\right)$} & 0.125 & 0.026 & 0.290 & 0.172 \\
\hline
\end{tabular}

\footnotetext{
${ }_{\mathrm{a}, \mathrm{b}}$ Different superscripts in a row indicate differ significantly $(P \leq 0.05)$
}

${ }^{c} \mathrm{CX}$ canthaxanthin, 25-OH-D 3 25-hydroxycholecalciferol 
increased pigmentation status of males in the CX and $25-\mathrm{OH}-\mathrm{D}_{3}$ mixture supplemented groups might play important roles in the expression of secondary sexual characteristics $[8,40]$ and worth further investigation. Interestingly, no effects were observed in antioxidant and pigmentation (data not shown) status of duck breeder females. It is noteworthy that maternal dietary antioxidants and pigments could be effectively transferred to the egg yolk, subsequently absorbed into the developing embryo, and distributed in the progeny tissues [7]. In this regard, the increased dietary vitamins and the $\mathrm{CX}$ and $25-\mathrm{OH}-\mathrm{D}_{3}$ mixture were more likely to be transferred to breeder eggs but not deposited in tissues of breeder females. This is highly consistent with the current observations on antioxidant and pigmentation status of breeder eggs, and suggest the possible use of maternal antioxidants and pigments to promote the quality of newly hatched ducklings.

\section{Conclusions}

HIGH vitamin premix made no effect on egg production and egg quality, but enhanced the antioxidant status of eggs and breeder males, and increased hatchability. The supplementation of the mixture of $\mathrm{CX}$ and $25-\mathrm{OH}-\mathrm{D}_{3}$ increased egg shell quality and increased the pigmentation and antioxidant status of eggs and breeder males.

\section{Abbreviations}

25-OH-D: 25-hydroxycholecalciferol; ANOVA: analysis of variance; CBB: Coomassie brilliant blue; CX: Canthaxanthin; d: day; DNPH: dinitrophenylhydrazine; GLM: general linear model; LSmeans: leastsquare means; MDA: malondialdehyde; NRC: National Research Council; ROS: reactive oxygen species; SEM: standard error of measurement; wk: week.

\section{Competing interests}

The authors declare that they have no competing interests.

\section{Authors' contributions}

QFZ, BY, FC and KYZ contributed in the experimental design and manuscript revision. ZZR conducted the trial and composed the manuscript. SZJ helped in animal care and sample collection. ZWS and YX assisted in sample analysis. XMD, SPB, JPW and YHL were involved in experimental design and statistical analysis. All authors read and approved the final manuscript.

\section{Acknowledgments}

The authors are grateful for the financial support from National and Sichuan Provincial Science and Technology Projects (2014BAD13B02, 2014NZ0030 and 2013NC0047), Academy of Kechuang Feed Industry in Sichuan, as well as DSM (China) Ltd.

\section{Author details \\ ${ }^{1}$ Key Laboratory for Animal Disease-Resistance Nutrition of China Ministry of Education, Institute of Animal Nutrition, Sichuan Agricultural University, Chengdu 611130, Sichuan, China. ${ }^{2}$ DSM (China) Ltd., PuDong New Area 201203, Shanghai, P. R. China. ${ }^{3}$ DSM Nutritional Products Ltd., Animal Nutrition \& Health, Wurmisweg 4303, Kaiseraugst, Switzerland.}

Received: 19 August 2015 Accepted: 11 January 2016

Published online: 22 January 2016

\section{References}

1. National Research Council. Nutrient requirements of poultry. 9th Ed. Washington, Dc: Natl. Acad. Press; 1994.

2. Mccuaig L, Carlson H, Motzok I. Observations on hypervitaminosis A and hydropericardium in chicks. Poult Sci. 1972;51:1206-10.

3. March B, Wong E, Seier L, Sim J, Biely J. Hypervitaminosis E in the chick. J Nutr. 1973;103:371-7.

4. Aburto A, Britton WM. Effects and interactions of dietary levels of vitamins A and $E$ and cholecalciferol in broiler chickens. Poult Sci. 1998;77:666-73.

5. Aburto A, Edwards HM, Britton WM. The influence of vitamin A on the utilization and amelioration of toxicity of cholecalciferol, 25hydroxycholecalciferol, and 1,25-dihydroxycholecalciferol in young broiler chickens. Poult Sci. 1998;77:585-93.

6. Sklan D, Yosefov T, Friedman A. The effects of vitamin A, B-carotene and canthaxanthin on vitamin a metabolism and immune responses in the chick. Int J Vitam Nutr Res. 1989;59:245-9.

7. Surai A, Surai P, Steinberg W, Wakeman WG, Speake BK, Sparks NHC. Effect of canthaxanthin content of the maternal diet on the antioxidant system of the developing chick. Br Poult Sci. 2003;44:612-9.

8. Gray D. Carotenoids and sexual dichromatism in North American passerine birds. Am Nat. 1996;148:453-80.

9. Zhang W, Zhang KY, Ding XM, Bai SP, Hernandez JM, Yao B, et al. Influence of canthaxanthin on broiler breeder reproduction, chick quality, and performance. Poult Sci. 2011;90:1516-22.

10. Rosa A, Scher A, Sorbara J, Boemo L, Forgiarini J, Londero A. Effects of canthaxanthin on the productive and reproductive performance of broiler breeders. Poult Sci. 2012;91:660-6.

11. Bikle D. Vitamin D and immune function: understanding common pathways. Curr Osteoporos Rep. 2009;7:58-63.

12. Abdulrahim $S$, Patel $M$, Mcginnis J. Effects of vitamin $D_{3}$ and $D_{3}$ metabolites on production parameters and hatchability of eggs. Poult Sci. 1979;58:858-63.

13. Bar A, Sharvit M, Noff D, Edelstein S, Hurwitz S. Absorption and excretion of cholecalciferol and of 25-hydroxycholecalciferol and metabolites in birds. J Nutr. 1980;110:1930-4.

14. Soares J, Kerr J, Gray R. 25-hydroxycholecalciferol in poultry nutrition. Poult Sci. 1995;74:1919-34.

15. Atencio A, Pesti GM, Edwards HJ. Twenty-five hydroxycholecalciferol as a cholecalciferol substitute in broiler breeder hen diets and its effect on the performance and general health of the progeny. Poult Sci. 2005:84:1277-85.

16. Cherry Valley Co. Sm3 commercial duck management manual. Laceby, England; 2004.

17. Dsm Nutritional Products Ltd. Dsm vitamin supplementation guidelines. 12th Ed. Te Heerlen, Netherlands; 2011.

18. Leeson S. Vitamin requirements: is there basis for re-evaluating dietary specifications. World's Poult Sci J. 2007:2:255-66.

19. Jentzsch A, Bachmann $H$, Fürst $P$, Biesalski $H$. Improved analysis of malondialdehyde in human body fluids. Free Radic Biol Med. 1996;20:251-6.

20. Reznick AZ, Cross CE, Hu ML, Suzuki YJ, Khwaja S, Safadi A, et al. Modification of plasma proteins by cigarette smoke as measured by protein carbonyl formation. Biochem J. 1992;286:607-11.

21. Bradford M. A rapid and sensitive method for the quantitation of microgram quantities of protein utilizing the principle of protein-Dye binding. Anal Biochem. 1976;72:248-54.

22. Roland D, Harms R. The lack of response of 25-hydroxy-vitamin $D_{3}$ on Egg shell quality or other criteria in laying hens. Poult Sci. 1976;55:1982-5.

23. Torres CA, Vieira SL, Reis RN, Ferreira AK, Da Silva PX, Furtado FVF. Productive performance of broiler breeder hens Fed 25hydroxycholecalciferol. R Bras Zootec. 2009;38:1286-90.

24. Zang H, Zhang K, Ding X, Bai S, Hernandez J, Yao B. Effects of different dietary vitamin combinations on the egg quality and vitamin deposition in the whole Egg of laying hens. Rev Bras Cienc Avic. 2011;13:189-96.

25. Soares J, Ottinger M, Buss E. Potential role of 1,25 dihydroxycholecalciferol in egg shell calcification. Poult Sci. 1988;67:1322-8.

26. Tanka $Y$, Deluca $H$. Role of 1,25-dihydroxyvitamin $D_{3}$ in maintaining serum phosphorus and curing rickets. Proc Natl Acad Sci U S A. 1974;71:1040-4.

27. Robel $E$. The value of supplemental biotin for increasing hatchability of turkey eggs. Poult Sci. 1991;70:1716-22.

28. Lin Y, Chang S, Hsu A. Effects of supplemental vitamin E during the laying period on the reproductive performance of Taiwan native chickens. Br Poult Sci. 2004;45:807-14. 
29. Noble R, Lonsdale F, Connor K, Brown D. Changes in the lipid metabolism of the chick embryo with parental age. Poult Sci. 1986;65:409-16.

30. Sato M, Tachibana T, Furuse M. Total lipid and triacylglycerol contents in the liver of broiler and layer chickens at embryonic stages and hatching. Anim Sci J. 2006;77:526-31.

31. Naber E. The effect of nutrition on the composition of eggs. Poult Sci. 1979;58:518-28.

32. Surai P, Ionov I, Kuklenko T, Kostjuk I, Macpherson A, Speake B, et al. Effect of supplementing the hen's diet with vitamin a on the accumulation of

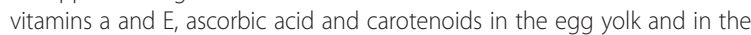
embryonic liver. Br Poult Sci. 1998;39:257-63.

33. Whitehead C. Nutritional influences on hatching eggs. Int Hatchery Practice. 2010;21:9-10.

34. Mohiti-Asli M, Shariatmadari F, Lotfollahian H, Mazuji M. Effects of supplementing layer hen diets with selenium and vitamin E on Egg quality, lipid oxidation and fatty acid composition during storage. Can J Anim Sci. 2008:88:475-83.

35. Surai P, Noble R, Speake B. Tissue-specific differences in antioxidant distribution and susceptibility to lipid peroxidation during development of the chick embryo. Biochim Biophys Acta. 1996;1304:1-10.

36. Gaal T, Mezes M, Noble R, Dixon J, Speake B. Development of antioxidant capacity in tissues of the chick embryo. Comp Biochem Phys B. 1995;112:711-6.

37. Nadia R, Hassan R, Qota E, Fayek H. Effect of natural antioxidant on oxidative stability of eggs and productive and reproductive performance of laying hens. Int J Poult Sci. 2008;7:134-50.

38. Couch J, Farr F. The effect of adding canthaxanthin and beta-Apo-8'carotenal to laying diets containing yellow corn and alfalfa on egg yolk pigmentation. Br Poult Sci. 1971;12:49-55.

39. Yue DB, Yan $L Y$, Luo HL, Xu X, Jin XX. Effect of vitamin E supplementation on semen quality and the testicular cell membranal and mitochondrial antioxidant abilities in aohan fine-wool sheep. Anim Reprod Sci. 2010:118:217-22.

40. Siitari $H$, Huhta $E$. Individual color variation and male quality in pied flycatchers (Ficedula hypoleuca): a role of ultraviolet reflectance. Behav Ecol. 2002;13:737-41.

\section{Submit your next manuscript to BioMed Central and we will help you at every step:}

- We accept pre-submission inquiries

- Our selector tool helps you to find the most relevant journal

- We provide round the clock customer support

- Convenient online submission

- Thorough peer review

- Inclusion in PubMed and all major indexing services

- Maximum visibility for your research

Submit your manuscript at www.biomedcentral.com/submit

) Biomed Central 